INFORMASI - ISSN (p) 0126-0650; ISSN (e) 2502-3837

Vol. 49. No. 1 (2019).pp 25-35.doi: http://doi.org/10.21831/informasi.v49i1. 24505

\title{
THE LANGUAGE USE OF SEX ARTICLES IN WOMEN LIFESTYLE MAGAZINE IN INDONESIA: CASE STUDY OF COSMOPOLITAN INDONESIA
}

\author{
Dian Sarwono \\ dsarwono@binus.edu \\ Faculty of Computing and Media \\ Bina Nusantara University
}

\begin{abstract}
The choice of words is one of important aspects in writing articles in printed media. Creative language use in lifestyle magazine may create interest for readers. The purpose of this research is to analyze the language use in sex articles in Cosmopolitan Indonesia. Launched in 1997, Cosmopolitan Indonesia is the first licensed Indonesian women lifestyle magazine and the first women magazine in Indonesia that openly discusses sex. This marks a change in Indonesian printed media. Before the publication of Cosmopolitan, sex and intimacy were only discussed in non-public spheres. Although the topics are discussed openly, the magazine uses special terms to describe man and women genital organs. After 22 years, Cosmopolitan Indonesia is still using the same terms in its sex articles, despite the fact that other women magazines are now discussing sex more openly and most of them are using the medical terms to describe genital organs. The focus of this research is mainly on what factors that consider Cosmopolitan Indonesia to use special terms in sex articles. The methodology will include purposive sampling interview and content analysis of 6 editions of Cosmopolitan Indonesia. The findings of this research may help the media and journalists to be more creative in choosing words for particular articles to attract readers interest, also to established the media unique identity, especially for lifestyle magazine.
\end{abstract}

Pemilihan kata-kata adalah aspek penting dalam penulisan artikel dalam media cetak. Bahasa yang kreatif digunakan dalam penulisan untuk majalah gaya hidup agar menarik perhatian pembaca. Tujuan dari penelitian ini adalah untuk menganalisis penggunaan Bahasa pada majalah Cosmopolitan Indonesia. Diterbitkan tahun 1997, Cosmopolitan Indonesia adalah majalah gaya hidup berlisensi Internasional untuk perempuan pertama dan majalah perempuan pertama di Indonesia yang mendiskusikan topik seks secara terbuka. Hal ini menandai perubahan pada sejarah media cetak di Indonesia. Sebelum terbitnya majalah Cosmopolitan Indonesia, seks dan hubungan intim umumnya tidak didiskusikan secara terbuka pada media cetak. Walaupun topik-topik didiskusikan secara terbuka, majalah ini tetap menggunakan istilah tersendiri untuk menggambarkan alat kelamin lelaki dan perempuan. Setelah 22 tahun, Cosmopolitan 
Indonesia tetap menggunakan istilah istimewa untuk artikel seks, walaupun majalah perempuan lainnya kita telah membicarakan seks dengan lebih terbuta dan umumnya menggunakan istilah medis untuk menggambarkan alat kelamin. Fokus dari riset ini adalah untuk mengetahui faktor apa saja yang membuat Cosmopolitan Indonesia mempertimbankan untuk memilih istilah khusus dalam penulisan artikel seks. Metodologi yang digunakan adalah purposive sampling interview dan content analysis dari 6 edisi Cosmopolitan Indonesia. Penemuan hasil riset ini diharapkan dapat membantu media dan jurnalis untuk lebih kreatif dalam memilih kata-kata untuk beberapa artikel spesifik untuk menarik perhatian pembaca, juga membentuk identitas unik sebuah media, khususnya majalah gaya hidup.

Keywords: Sex, Indonesian Women, Indonesia,

\section{INTRODUCTION}

This research aims to study the language use of sex articles in Cosmopolitan Indonesia. The magazine is the first women lifestyle magazine in Indonesia that discusses sex openly. However, it uses special terms when describing genital terms in its sex articles. The researcher would like to find out the reasons of using the special terms in writing sex articles.

Indonesia is more governed by tradition than any Western country. However, Indonesia is in the process of becoming or wanting to become modernised but still wants to hold on to its tradition for fear of losing its identity. In this process, conflicts often arise, specifically because Indonesia has the biggest Moslem population in the world. A good example of what has created conflict is the changing image of Indonesian women. Some people in Indonesia are still very much influenced by tradition. On the other hand, the growing Western influence in the country creates a different view of Indonesian women's identity in a modern world.

The Indonesian media has more and more adopted images of women shown on International television channel and International magazines. This embracing of Western images of women is probably not confined to Indonesia but is a part of the globalisation phenomenon that is taking place around the world (Harlim, 200o). In the last couple of generations, images of
Women Magazine, Lifestyle, Cosmopolitan

Indonesian women have started to change and look more like women presented in the West. In these modern times, women still retain their Indonesian-ness and this reflected in popular magazines.

One reflection of this is in women's magazines from the West. These magazines try to adapt to Indonesian culture and norms; however, thecontent is stillvery Western. They have become a part of Indonesian popular culture, especially in big cities. One good example of such a magazine is Cosmopolitan Indonesia. The magazine was first launched in August 1997, as a co-operation between PT. Higina Alhadin and Hearst International. The magazine was first published with the name Higina Kosmopolitan before it became Kosmopolitan. The Indonesian version spells the word Cosmopolitan with $\mathrm{K}$ instead of $\mathrm{C}$. This is probably because it wants to adjust to the pronunciation conventions of the Indonesian language. However, in August 2001, the magazine changed its spelling into Cosmopolitan and published by MRA (Mugi Rekso Abadi) Printed Media Group. Besides Cosmopolitan Indonesia, the publisher has other licensed women magazine titles, they are Harper's Bazaar Indonesia, her world Indonesia, and Mother \& Baby Indonesia. The readers of Cosmopolitan Indonesia are women between 18 - 34 years old, single, and career women who represents modern women (www.mra.co.id/index). There have been a lot of changes since the magazine first launched. It used to be more like other Indonesian women magazines, which 
usually have recipes, fictions, and Indonesian models. It changed its format because from the magazine survey information, it was found that Cosmopolitan readers no longer need recipe-probably because most of the readers are workingwomen. Its motto is the fun fearless female magazine. Cosmopolitan Indonesia wants the reader to be a fun fearless female, confident about herself, with the courage to express her opinions and always see everything in a positive way (www.mra.co.id/ index). The majority content of the magazine is similar to other Cosmopolitan magazine around the world also other women lifestyle magazines, which featured articles about fashion, beauty, work, latest news updates on travel, food, celebrities, health also sex and relationships. The articles and pictures presented in the magazine make it look very similar to other editions of Cosmopolitan magazines around the world. However, it is interesting to note that Cosmopolitan Indonesia is using special terms to describe male and female genital organs. The magazine is using "Mr. Happy" to describe a penis and "Mrs. Pretty" or Miss. Cheerful to describe a vagina. Although sex has become an open discussion in Cosmopolitan Indonesia, it seems that mentioning the word penis or vagina is still considered impolite for Indonesian women, even for medical terms. This is also a way of infantilizing people, as well as being taboo. For example:

Bagaimana Anda bisa mengharapkan sang pasangan untuk tahu cara membuat Anda berorgasme jika Anda sendiri tidak tahu caranya? Luangkan waktu Anda untuk lebih mengenal Miss Cheerful dengan tips masturbasi dari Cosmo. (Cosmopolitan Indonesia, Februari 2018, Mengapa Wanita Tidak Bisa Mengalami Orgasme?)

[How could you expect him to know ways to make you reach orgasm if you don't even know how to do it? Take some time to know Miss Cheerful with tips from Cosmo]. (Cosmopolitan Indonesia, February 2018, Why Women Can't Reach Orgasm?)
Pikiran seperti "Apakah payudara saya terlihat rata dari angle ini?" atau "Wah, tubuhnya berkeringat sekali," akan membuat Anda kehilangan fokus. Daripada mencemaskan hal yang tidak penting, lebih baik pusatkan pikiran ke sensasi gesekan Mr Happy di dalam Anda. (Cosmopolitan Indonesia, Februari 2018, Mengapa Wanita Tidak Bisa Mengalami Orgasme?)

[If you are busy thinking about "Do my boobs look flat from this angle?" or Wow, he is sweating," then you will lose focus. It's better to think of the sensation of Mr Happy inside you]. (Cosmopolitan Indonesia, February 2018, Why Women Can't Reach Orgasm?)

Today, Indonesia has a list of lifestyle magazine targeted for women age 18-45 that discuss sex openly. However, most of them do not use special terms to describe genital organs. While, Cosmopolitan Indonesia are still using those special terms for sex articles until today. For example:

Frenulum merupakan garis di bagian penis yang mudah bereaksi terhadap rangsangan dan peka terhadap sentuhan ringan dan lembut. Bagian ini merupakan sumber kenikmatan paling istimewa. (her world Indonesia, Desember 2016, Blow Me, Baby)

[Frenulum is a line on penis that easily create reaction and sensitive to soft touch. This part is the source of sensation]. (her world Indonesia, December, 2016, Blow Me, Baby)

Bosan dengan posisi klasik "69"? Anda bisa mencoba gaya ini. Angkat pinggul Anda dan jauhkan dari mulutnya, biarkan ia memainkan vagina Anda menggunakan jari. (her world Indonesia, Desember 2016, Blow Me, Baby)

[Bored with the classic "69"? You can try this move. Lift your hip and apart from his mouth, let him play with your vagina using his fingers]. (her world Indonesia, December 2016, Blow Me, Baby) 
The researcher took examples from her world Indonesia, a licensed magazine from Singapore as the magazine also produced sex and relationship articles regularly and have similar readership characteristics.

According to Filisya Thunggawan, Editor-in-Chief of Cosmopolitan Indonesia (personal interview, 22 November 2018), "At first, the term Mr Happy and Miss Cheerful were adapted from Cosmopolitan USA, it was not mandatory, there are other Cosmopolitan magazines in other countries that don't use the terms." Cosmopolitan Indonesia also use other terms such as rudal to describe male genital organs to avoid repetitive words in writing, but never use the terms penis and vagina. "We choose to use the terms to create a character of Cosmopolitan Indonesia, also to keep the consistency in writing, it has nothing to do with Indonesian culture." Moreover, the terms could create a more casual and fun language especially for sex articles.

Topics for sex articles in Cosmopolitan Indonesia are not always on sex information as entertainment, for example sex position, orgasm, but also sex knowledge as education such as healthy reproduction, birth control, genital diseases. Although the choice of terms that Cosmopolitan Indonesia used to describe genital organs has nothing to do with culture, however, according to Filisya Tunggawan (personal communication, 22 November 2018), "Majority of Cosmopolitan readers would like to gain knowledge about sex, but do not want to discuss sex openly. They'd preferred to be passive readers. For example, inside the Cosmopolitan Indonesia community, whenever there was a survey with sex as a topic, the number of respondents were very little compare to topics like career, love or money. Another example is in social media, if there was a post contain sexy picture, the number of likes is little. "This is most likely related to culture, most of Cosmopolitan Indonesia readers apparently do not want to be perceived to enjoy reading sex articles."

\section{LITERATURE REVIEW}

There is a range of studies about women magazines throughout the history of popular women magazines. Most of the work approaches the topic by investigating the covers, editorial contents and articles. There is a study about style of global magazine with Cosmopolitan magazine as a case study. Machin \& van Leeuwen (2005) find out that in the case of Cosmopolitan magazine, every country tries to create unique characteristics to adapt with culture, however, it still follows the global style. Ytre-Arne (2011) look at content analysis on women magazines and tries to look at the readers' point of view. McCracken (1993) and McRobbie (2000) view at a magazine as a whole, from cover, editorial, articles and pictures. Every section of women's magazines represents images of women. While reading the magazine, a woman finds her ideal image and performs an enjoyable activity by combining her real life and fantasy (McCracken, 1993). Both Weibel (1977) and Zoonen (cited in Strinati, 1995) look at the representation of women in magazines. The latter argues that images of women in the media are: mother, wife, girlfriend or working in traditionally female jobs, such as secretary, nurse, receptionist, or as sex object. In the same way, Weibel (1977) stresses that over the past century, the image of women in magazines has been portrayed mostly in domestic roles by popular culture. On the other hand, Tuchman (cited in Strinati, 1995) argues that women magazines aimed at a largely working-class readership are more likely to show women at work, and as being independent and effective, than magazines aimed at a predominantly middle class readership. These theories about the images of women reflect the changing images of women in Indonesian magazines. In the 8os, the images in Indonesian magazines were like these images described by Weibel (1977) and Zoonen (cited in Strinati, 1995). In today's world, the images are more and more like women in the Western world: 
working women, confident and courageous.

Other studies of women's magazines examine the meaningfulness of the magazine. Hermes (1995) sees that women's magazines as text are not very important; however, they are important as everyday media because they help women to relax without interrupting their routine. However, Winship (1987) argues that women's magazines do a lot more than that. They appeal to their readers by combining entertainment and advice. They try to draw the readers into the world of magazines and in the end into a world of consumption. They are important because they are full of practical information and have become a way of keeping in touch with the changing culture. Kim (2012) supported the idea of Winship's research that by reading women magazine are informed with topics that they are afraid to ask, for example sex. According to Kim's information about sex could women find their sexual identities. This research also related to study by Attwood (2015) that focus on the media as one of the sources of sex advice and education have to be careful in selecting words.

The researcher also look at studies on the use of language in advertising using foreign language. Nederstight \& Hillberink-Schulpen (2017) found that there is a connection between the effective advertisement and the language use, although the foreign language may not be the only factors to create an effective advertisement. However, according to their study, it might help the consumer to become familiar with the product. The researcher believed this is almost similar with the case of special terms that are being used to write sex articles in Cosmopolitan Indonesia. Some women readers are more comfortable reading special terms in foreign language than reading the medical terms of genital organs.

The purpose of this research is to find out what factors that consider Cosmopolitan Indonesia to choose words and terms for the sex articles plus why Cosmopolitan consistently using those special terms until today. This study also aims to extend the study about women's magazines by
Winship (1987) in Britain in the 1980s. In Inside Women's Magazines, Winship (1987) discusses Cosmopolitan. There are three main focuses that she examines in this chapter, firstly, the portrait of Cosmopolitan, which discusses about the readership profile, the advertisement and the articles. Secondly, it discusses the sexual reputation of Cosmopolitan because of its articles. Lastly, it discusses the feminist strengths of the magazine. Winship provides a framework that will be adapted in this research. Specifically, it also discusses the scope of research going to be discussed, which are articles on sex. Despite the changes, Winship's study is still relevant. The study will contribute to the field of women's lifestyle magazines and journalism in Indonesia, especially on writing articles on sex and relationship.

\section{METHODS}

The methodology used for this study are purposive sampling and content analysis. According to Ekitan, Musa, \& Alkasim (2016), purposive sampling is a non-random technique which allow the researcher to specifically choose the participants due to their knowledge and qualities about particular topic. The participants were chosen to provide better information on the relevant research. The purposive sampling method for this study is homogeneous sampling as stated by Ekitan, Musa, \& Alkasim (2016), this method focuses on participants with particular characteristics, for example age, culture, jobs, experience that may help the researcher to relate with the topic being investigate. This method fits this study as the researcher need to find participants who are familiar with women lifestyle magazines and regularly read them. This may not be achieved with random participants.

This study will also use content analysis, according to Krippendorff (2018), content analysis is a research method to analyse content of communication material by using certain procedures for example clarification and evaluation. For analysis, six editions of 
Cosmopolitan Indonesia from May 2018 October 2018 will be chosen to specify the scope of the research. Specifically, the articles on 'sex and relationships'. Six participants were chosen for the purposive sampling interview. They are all women ages between 22-40 years old, first jobbers and career women, and regularly read women lifestyle magazines. All of them are familiar with Cosmopolitan Indonesia magazine and other women lifestyle magazine that also provide sex article like Cosmopolitan Indonesia. The content analysis will examine how the special terms Mr. Happy and Ms. Cheerful are being used. Moreover, to see the style of writing for sex articles in Cosmopolitan Indonesia. The purposive sampling output will provide understanding of readers' preference on the use of terms for sex articles.

\section{RESULTS AND DISCUSSION}

The outcome of this study is to provide recommendation to Indonesian journalists on how to use language in sex articles in women lifestyle magazine. This study also serves as a preliminary research on the consistency of writing style in a magazine.

There are 16 articles on sex and relationship being analyzed from six editions of Cosmopolitan Indonesia from May 2018 October 2018. In every issue of the magazine, there are ten sections: regular column (astrology, shopping information, letter from the editor), Celeb World (cover story and celebrity news), Fashion, Beauty, Youniverse (feature stories), Work, Fashion \& Beauty (fashion and beauty pages photoshoot), Love Lust (sex and relationship), Body (health and exercise), and Life (travel and new places).

Firstly, an interesting finding was found from the cover of the magazine, although every month there is always feature article on sex, however, the title of the sex articles never appeared on the covers, only the title of relationship articles. There was an assumption that Cosmopolitan Indonesia would use the title of sex articles on the cover as one of its selling point, the content analysis showed different result. This finding relates to Machin \& van Leeuwen (2005) study that said the global style will be applied to local editions, however, each magazine will still adjust it with the local culture. This finding also strengthened the study by Barrow (2016) that analyzed covers of Cosmopolitan U.S, U.K, Chile, and Hong Kong in 2015. Both Cosmopolitan U. S and U.K used sex articles on the cover, but not Cosmopolitan Chile and Hong Kong.

Secondly, the topics of sex articles are varied from sex education such as sex positions, orgasm, foreplay, to health information for example sexual disease, menstruation, Q\&A with gynecologist. The magazine always used the term Mr. Happy and Miss Cheerful to describe genital organs of male and female, not only for sex articles but also on topics on health information. There are other terms that the magazine use to describe genital organs, for example rudal (missile) to describe male genital organ, to avoid repetitive words, but the researcher didn't find the words penis and vagina.

For example:

Kami menyebutnya Summer Fling! Dari posisi missionari kaitkan kaki Anda di pundak si dia dan naikkan pinggul Anda (supaya ia bisa meraih Miss Cheerfuldari sudut yang pas). Kemudian minta dia memegang pinggul saat menjatuhkan kepala dan lengan ke lantai. Sudut ini memberikan Mr. Happy sensasi sesak dan menyerang G-Spot Anda dengan hebat! (Cosmopolitan Indonesia, Mei 2018, Hmmm... Vacation Sex!)

[We call it Summer Fling! From missionary position put your legs on his shoulder and lift your hip (so that he could reach Miss Cheerful from the right angle). Then ask him to hold your hip when you put down your head and arms on the floor. This angle could give Mr Happy full sensation to attack your G-Spot!] (Cosmopolitan Indonesia, May 2018, Hmmm... Vacation Sex!)

Thirdly, the magazine used medical terms for other words such as clitoris, labia minora, pubic line but never for genital organs. 
For example:

Dengan mata telanjang klitoris mungkin hanya terlihat seperti tombol kecil. Namun, itu hanyalah 1/4 dari ukuran klitoris wanita. Baru-baru ini, para peneliti telah menemukan kalau volume rata-rata klitoris yang tak terangsang bervariasi antara 1.5 sampai $5.5 \mathrm{~mm}$. Wow! (Cosmopolitan Indonesia, Juli 2018, 13 Fakta Soal Titik Orgasme Wanita Alias Klitoris)

[With naked eyes clitoris probably can only be seen as tiny button. However, it is actually only $1 / 4$ of the size of a woman's clitoris. Recently, researchers have discovered that the average volume of the non arouse clitoris varied between 1.5 to $5.5 \mathrm{~mm}$. Wow!] (Cosmopolitan Indonesia, July 2018, 13 Facts of Woman's Orgasm)

Fourthly, for health articles that require stating genital organs, Cosmopolitan Indonesia always use the terms Mr. Happy and Miss Cheerful.

For example:

Menggunakan tampon organik, apakah lebih aman untuk kesehatan Miss Cheerful? (Cosmopolitan Indonesia, Oktober 2018, Gyno Q \&A)

[Is using organic tampon safer for Miss Cheerful health being?] (Cosmopolitan Indonesia, October 2018, Gyno Q E A)

Impotensi! Gangguan seksual satu ini jadi musuh paling besar para pria. Anda bisa bayangkan seperti apa jadinya bila Mr. Happy-nya tidak bisa berfungsi dengan baik dan tidak mampu ereksi maksimal. Yup, mimpi paling buruk. Jadi, bantu si dia untuk menjaga kesehatan dan pola hidup sehat agar mimpi buruknya ini tak pernah terjadi. (Cosmopolitan Indonesia, Juni 2018, Permasalahan Tubuh Yang Pria Takuti)

[Impotent! This is probably most men enemy. Can you imagine what is it like for his Mr. Happy if it can not function well? Yup, nightmare. So, you need to help him to take care of his health and maintain healthy lifestyle. Hopefully this nightmare will not happen to him.] (Cosmopolitan Indonesia, June 2018, Health Nightmares for Men)

Winship (1987) points out that Cosmopolitan shows that sex is not only a topic of discussion for men, but women also have a right to discuss the topic of sex. Similarly, Weibel (1977) emphasis that Cosmopolitan is not like Playboy magazine, although some people think that it is a woman's version of Playboy; however, it is true that Cosmopolitan discuss sex but these discussions are arrange in such way so that they become appropriate for women. MacDonald (1995) argues that Cosmopolitan has explored an honest opinion about sex.

The sex articles are indeed popular and probably have become one of the key selling points. However, Cosmopolitan is not a sex magazine, sex is not the main concern of the magazine. There are other topics that are also important and also have developed a particular image of the magazine, which is a magazine for modern women who are confident, courageous and open minded.

Winship (1987) states that there is a common structure in Cosmopolitan articles. There is always a personal problem, then exploration of the problem by combining knowledge and opinion from 'the experts', it can be a psychologist, writers, lawyers or the author's own opinion and they always come up with the strategies to solve the problem. Some conclusions can be drawn based on the analysis of some articles in both versions. Winship's theory about the structure of articles in Cosmopolitan is applicable to Cosmopolitan Indonesia as well.

Fifth, the style of the 'sex' articles followed the common structure of other articles. The language being used is everyday language, which is usually used by young people and easy to understand. However, there are some differences in the choice of words for these articles. The Indonesian version mostly uses suami (husband) and istri (wife) in articles about sex and relationships, although sometimes pasangan (partner) or si Dia (him or her) also has been used. The 
magazine never uses boyfriend or girlfriend in its articles on sex and relationships because most Indonesians still consider that sex is a discussion for married people.

For example:

Kirimkan tiga foto benda yang dapat membuat sesi bercinta semakin seru kepada pasangan Anda. Contohnya foto dasi berbahan sutra, massaging oil, dan es krim. Minta si Dia untuk memilih satu dan gunakan benda tersebut untuk permainan nanti malam. (Cosmopolitan Indonesia, Oktober 2018, From Dusk to Dawn, Get Your Sex Game On)

[Send three pictures of objects that could create sex session more pleasurable to your partner. For example a picture of silktie, massaging oil, and ice cream. Ask him to choose one and use that object for tonight's game.] (Cosmopolitan Indonesia, October 2018, From Dusk to Dawn, Get Your Sex Game On)

The researcher prepared ten main questions for the purposive sampling interview. The questions were formed to find out the participants opinion about sex articles on women lifestyle magazine, how they perceive sex articles, and their thoughts about the use of special terms to describe genital organs on sex articles in women lifestyle magazine.

The researcher summarizes the result of interview as follows. First, all participants think that sex article is important as regular content in women lifestyle magazine. One participant says," It's important because it educates women who are in need of certain information and it also helps those to relate with their own story. Sex articles are not something taboo to discuss, it's humane and part of life, it's actually healthy to talk about it's a topic that should stick around in women lifestyle magazine." (22 year-old public relation officer). According to another participant, "Sex article in women magazine is important because not every friend wants to discuss about sex, the magazine can somehow be that friend, especially because the magazine could also provide the answer that you need. Moreover, not everybody has a fantastic sex life, we still need ideas or inspiration in bed, and we get that from the magazine." (41 year-old wedding decorator)

Second, most of the participants read sex articles in women lifestyle magazine, however not regularly. Majority says usually they read the article because the topic is interesting or something they need or a new topic. All of them don't mind if others know that they read sex articles in women magazine. "It's not something to be embarrassed about, "According to one participant. (45 year-old banker). While another says, "It's really okay, if the friends are cool, we can even discuss the topic together." (22 year-old student).

Third, two participants say they read sex articles in women magazine to gain information and entertainment. "I believe the information that I read from the magazine is from reliable sources, I gain knowledge from it, and it is also entertaining because usually the writing style for sex article is using interesting language (not dirty) that makes sex articles always entertaining to read." (35 year-old graphic designer). Only one participant say they read sex article mainly for entertainment. "Usually the topics for sex articles are light and fun." (41 yearold wedding decorator). While the rest of participants say that they read sex article to gain information. Besides reading sex articles from women magazine, all participants also find information about sex from other sources for example book or the internet.

Fourth, five out of six participants think that the language use for sex articles in women magazine is different compare to the language use in other sources like book or the internet. "The language used is more expressive, casual, and fun, we could read different language styles from different writers." (38 year-old academic consultant). Other participant says that, "Usually the language used in the magazine is more polite, not vulgar." (45 year-old banker). Different participant adds that, "The length of article in the magazine is longer and the discussion is deeper than the one on the internet, the language is easy to understand and not too 
complicated." (35 year-old graphic designer). Another participant also adds that, "The sex article in women magazine share information rather than fantasies, they are informative and appropriate." (22 year-old student). While one participant say, "In the women magazines or on the internet, I mostly read sex articles for entertainment only, so I think the language that they used are basically similar." (41 year-old wedding decorator).

Fifth, to respond the question about the use of special terms to describe genital organs in sex articles, three participants say that they think the magazine do not need to change the terms into specific terms. However, the other three participants say that they prefer the special terms. "I like the terms Mr Happy and Miss Cheerful than penis and vagina, because I think the terms are more polite." (45 year-old banker). The other participant says, "It's better to change the terms to create more variation in describing genital organs."

(41 year-old wedding decorator). While the other participant says, "The magazine doesn't have to change the terms, however, it is fun to read various terms." (22 year-old student)

Sixth, all participants think that the main reason for women magazine to use special terms to describe genital organs is probably to create more polite conversation. "Maybe because they think the original terms of genital organs areimpolite or taboo, because the norms that are implemented in Indonesia since a long time ago. This can also be seen by the habits of parents when teaching their children the terms of genital organs, where mostly they used other terms instead of the original ones." (38 year-old academic consultant)

From the result description from the content analysis and purposive sampling interview, the researcher could draw some outputs in relation to writing in lifestyle magazine.

1. Features articles are the most suitable writing forms for sex and relationship articles. A study by Wheeler (2009) sees that one characteristic of feature story is the different approach, there is no specific format. The writer could use various style for the topic. In Cosmopolitan Indonesia, every month the story format for sex articles are always different, narration, Q\&A format, column with expert, series of pictures, problem-solution, etc.

2. The sex articles in Cosmopolitan Indonesia are always accompany by pictures or illustrations. Pape \& Featherstone (2006) explains features story are longer than news articles and always use photographs, tables, illustrations, boxes, graphs. In the case of writing articles, these additions are important to make the articles more interesting and fun to read.

3. Consistency is one of an important aspect in writing, especially for lifestyle magazine. Filisya Thunggawan, Editor-inChief, Cosmopolitan Indonesia stresses that the magazine would like to create characteristics in its sex and relationship articles to construct identity for the magazine (Personal communication, November 2018). From the responses of the participants during the interview, all of them directly know that the special terms Mr. Happy and Miss Cheerful are the terms that are being used in Cosmopolitan Indonesia.

\section{CONCLUSIONS AND RECOMMENDATIONS}

The image of modern women presented in Cosmopolitan Indonesia magazine is open minded, courageous, confident and positive, but still retaining their Indonesian values. Cosmopolitan Indonesia has become a part of popular culture for modern Indonesia women. It follows the format of Cosmopolitan in the West in its target audience and general image. However, Cosmopolitan Indonesia is also culturally specific. The magazine does not transfer all the formats, it filters them and adjusts them to Indonesian culture (Machin \& van Leeuwen). This is also related the globalisation theory propose by Tomlinson (1991), in dealing with globalising cultural forces; the individual culture does not just absorb the dominant culture, it translates, adapts, and indigenised to fit its own culture. From the six issue of Cosmopolitan Indonesia that are analysed, issues that are considered 
sensitive are not discussed, for instance, abortion, prostitution, and LGBT.

Although sex articles are one of the regular content, however the proportion of the articles are smaller than other feature articles, for example, career, self-acceptance, money, etc. This is probably because it wants to reflect to its motto as the fun fearless female magazine. It also shows that Cosmopolitan Indonesia has its own identity. Cosmopolitan Indonesia also covers articles on sex openly, but it is not the major content of the magazine. In its discussion on this particular topic, the choice of words and pictures are chosen carefully, so that they can still appropriate for Indonesian print media and readers. This study has demonstrated how popular media, in this case, Cosmopolitan Indonesia combining the modern and traditional values. Popular media, such as Cosmopolitan has opened some people's perception that sex is part of knowledge that women should know.

This research could be useful for journalist, especially on the importance of consistency in writing to build identity for the publication. It could also add input on how special feature like sex and relationships could be presented in a creative way. However, there are not many researches on women lifestyle magazine in Indonesia. Perhaps, in the future, this issue may be addressed and studies such as the influence that women lifestyle magazine has on Indonesian women may be acknowledge.

\section{ACKNOWLEDGEMENT}

This research is funded by Bina Nusantara University Internal Grant 2018.

\section{REFERENCES}

Attwood, F, Barker, M, Boynton, P, \& Hancock, J. Sense about Sex: Media, Sex Advice, Education and Learning, 528-539 https://doi.org/10.1080/146818 11.2015.1057635

Barlow, Kara W. “Cosmopolitan Goes Intercultural: A Semiotic Analysis of Cosmopolitan Magazine Covers" (2016). Linfield College Student Symposium: A Celebration of Scholarship and Creative Achievement. https://digitalcommons.linfield.edu/ symposium/2016/all/28

Cosmopolitan. (2017). Fun Fearless Female Magazine, http://www.mra.co.id/ index.php?option=com_content\&view $=$ article $\& i d=50 \&$ Itemid $=65, \quad$ Accessed 14 April 2019.

Hermes, J. (1995). Reading Women's Magazine, Polity Press, London.

Krippendorff, K. (2018). Content Analysis: An Introduction to Its Methodology, Sage Publication, London.

Etikan, I, Musa, S, \& Alkassim, R. Comparison of Convenience Sampling and Purposive Sampling. American Journal of Theoretical and Applied Statistics. Vol. 5, No. 1, 2016, pp. 1-4. doi: 10.11648/j. ajtas.20160501.11

Kim, J \& Ward, M (2012) Striving for Pleasure Without Fear: Short-Term Effects of Reading a Women's Magazine on Women's Sexual Attitudes. https://doi. org/10.1177/0361684312442856

Machin, D., \& van Leeuwen, T. (2005). Language style and lifestyle: the case of a global magazine. Media, Culture $\mathcal{E}$ Society, 27(4), 577-6oo. https://doi. org/10.1177/0163443705054151

McCracken, E. (1993). Decoding Women's Magazines, The Macmillan Press Ltd, London. 
McRobbie, A. (1991). Feminism and Youth Culture From 'Jackie \& Seventeen', Macmillan, London.

Nederstigt, U \& Hilberink-Schulpen, B. (2017). Just Advertising in a Foreign Language or the Consumers' Native Language? Journal of International Consumer Marketing, 2-13. https://doi. org/10.1080/08961530.2017.1363008

Pape, S., \& Featherstone, S. (2006). Feature Writing: A Practical Introduction, Sage Publication, London.

Tomlinson, J. (1999). Globalization and Culture, Polity Press, Cambridge.

Weibel, K. (1977). Mirror Mirror: Images of Women in Popular Culture, Anchor Press, New York.

Weber, R. (1990). Basic Content Analysis, Sage Publications London.

Weeler, S. (2009). Feature Writing for Journalists, Routledge, London and New York.

Winship, J. (1987). Inside Women's Magazine, Pandora, London.

Ytre-Arne, B. (2011). Women's magazines and their readers: The relationship between textual features and practices of reading. European Journal of Cultural Studies, 14(2), 213-228. https://doi. org/10.1177/1367549410389928 